\title{
PLASMA INSULIN ACTIVITY IN DIABETICS
}

By J. Vallance-Owen, M.A., M.D.(Cantab.), M.R.C.P.

Department of Medicine, King's College, University of Durham, Newcastle upon Tyne

A reasonably accurate and reliable method for estimating the insulin concentration of blood plasma should prove useful for studying many problems in metabolism, particularly those relating to diabetes mellitus.

The technical difficulties involved in this determination are considerable. Not only is a very sensitive method required to measure the minute quantities of insulin present in plasma, but any such method must be quantitative over the range of insulin concentration encountered. Nevertheless, a number of assay procedures have now been described which are sufficiently sensitive for this estimation. They fall broadly into in vivo techniques and in vitro techniques.

The in vivo methods depend on the hypoglycaemic effect of insulin. The test animals used have been prepared in various ways to increase their sensitivity. Gellhorn et al. (194r) used hypophysectomized - adrenodemedullated rats and found that 200 micro-units of insulin gave a small but significant lowering of the blood sugar of this preparation. In 1947 Anderson and her colleagues prepared hypophysectomized-adrenodemedullated rats, previously rendered diabetic with alloxan to prevent the possibility of variation in the rate of secretion of endogenous insulin. Bornstein (1950), using a modification of the above technique, obtained significant effects with insulin doses as low as 50 micro-units. He prepared alloxan-diabetic hypophysectomized adrenalectomized rats (ADHA rats). Undiluted plasma is used in the assay.

The technical difficulties involved in the preparation and maintenance of these animals and the actual conduct of the assay itself are considerable. In view of this, a relatively simple in vitro technique employing the isolated rat diaphragm has been extensively studied over the past few years (e.g. Groen et al., 1952; Vallance-Owen and Hurlock, I954; Randle, 1954; Wright, 1957).

This in vitro method depends on the fact that small amounts of insulin increase the utilization of glucose by the isolated rat diaphragm (Gemmill, I94 I) and that a quantitative relationship exists between the concentration of insulin in the in- cubation medium and its effect on the glucose metabolism of the diaphragm. By rigorous control of the experimental conditions, the method becomes extremely sensitive, measuring as little as ro micro-units insulin $/ \mathrm{ml}$., which is quite sufficient for estimating normal plasma levels.

It has now been shown that plasma contains factors other than insulin that can affect the assay procedures. Thus it must be emphasized that the results obtained using whole undiluted plasma, either with the in vivo methods, or in the rat diaphragm procedure, indicate the effective insulin concentration or insulin activity of the plasma. This is the sum of the biological effects of insulin and its synergists, if any, on the one hand and its antagonists on the other. However, it is also apparent, from recent experiments with the rat diaphragm, that dilution of whole normal plasms neutralizes, in part at any rate, the effect of some insulin antagonist in undiluted plasma or, alternatively, releases insulin from some bound inactive form.

Therefore, investigators using undiluted plasma with the rat diaphragm technique have obtained lower values for insulin activity than those using diluted plasma. This point is stressed, as it has given rise to confusion, not only over normal values, but also in the interpretation of results relating to the plasma insulin activity in diabetes mellitus. The evidence which suggests that insulin activity is indeed being estimated in plasma by the rat diaphragm procedure can be summarized briefly:

(I) There is no measurable plasma insulin activity after pancreatectomy in cats and dogs.

(2) The increased glucose uptake from standard solutions of insulin and from plasma can be removed by cysteine and glutathione; insulin loses its activity in the presence of such $\mathrm{SH}$ compounds.

(3) Patients with spontaneous hypoglycaemia from islet-cell tumours have excessively high levels of plasma-insulin activity, both in the fasting state and after oral glucose. These levels fall into the normal range after the tumour has been removed.

(4) Antiserum against beef insulin prepared in a 
TABLE I

Insulin Activity in Plasma from Normal Subjects

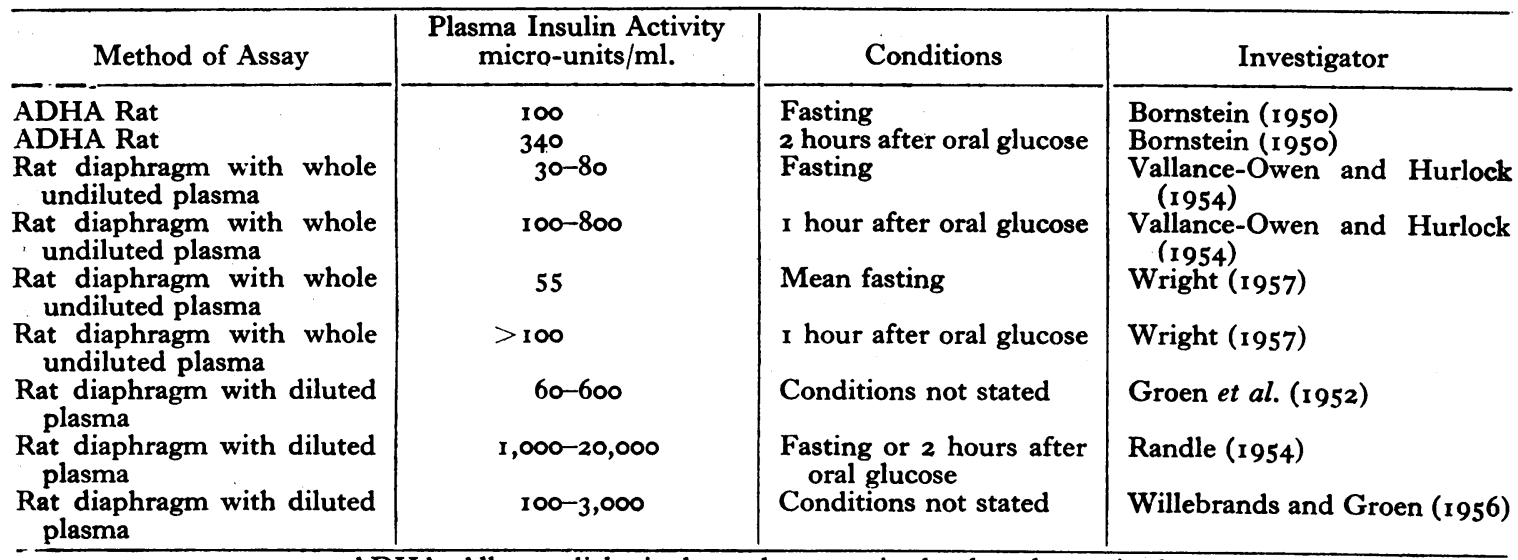

ADHA, Alloxan-diabetic, hypophysectomized, adrenalectomized.

guinea-pig will abolish the increased glucose uptake from standard solutions of beef insulin and from the plasma of a cow (Wright-personal communication).

It has been suggested that the insulin-like action of plasma on the rat diaphragm was due to a nonspecific effect of plasma albumin. However, it now seems likely that the stimulating effect of such albumin fractions was due to the presence of insulin itself (Randle and Taylor, 1958).

Although there are now other in vitro methods for assaying insulin, e.g. that employing rat adipose tissue (Martin et al., 1958), they have not yet been used extensively.

\section{Insulin Activity in Plasma of Normal Subjects}

The values that have been obtained by different authors are shown in Table I. For simplicity only those investigators who have gone on to study plasma insulin activity in diabetes have been included.

In spite of the overall variation, those investigators using the ADHA rat technique and whole undiluted plasma in the rat diaphragm procedure have obtained reasonably comparable results; up to $100 \mathrm{micro}-\mathrm{units} / \mathrm{ml}$. for fasting samples. After oral glucose there was usually a considerable increase above this fasting level.

\section{Plasma Insulin Activity in Diabetes}

Interest has centred mainly around the two broad clinical groups of diabetic patient (Himsworth, 1949; Lawrence, 1951). In the first the patients, besides having hyperglycaemia and glycosuria, usually develop ketosis and rapidly lose weight unless given insulin treatment, to which they are generally sensitive. The second group do not require insulin and show no tendency to ketosis unless their diabetes is complicated by infection. These patients are usually obese, often recover from the diabetic state when they lose weight on a low carbohydrate reducing diet, and are relatively insensitive to insulin injections.

The ADHA rat in vivo technique and the rat diaphragm procedure have been used for the study of plasma insulin activity in these patients.

When the ADHA rat method was used (Bornstein and Lawrence, I95I) the untreated patients who had markedly elevated fasting blood sugar levels were all prepared in the same way. They were given $50 \mathrm{~g}$. oral glucose and the blood was collected two hours later, in order to stimulate any possible insulin secretion in a comparable manner.

The mild obese group all had insulin activity in their plasma. The mean activity was 230 microunits/ml., which was about 70 per cent. below the mean value of 340 micro-units $/ \mathrm{ml}$. found in normal subjects treated in the same fashion.

On the other hand, those patients, classed as severe, who were losing weight and who subsequently needed insulin to prevent ketosis, had no measurable plasma-insulin activity. When the patients in this group received insulin treatment so that their blood sugar was physiological at the time of the test, insulin activity was found in their plasma at a mean level of 230 micro-units $/ \mathrm{ml}$.

It was also noted that there was another clear difference between these groups: the ADHA rats used for testing the inactive diabetic plasma were rendered insensitive to insulin in subsequent control tests. This was not the case with the rats used for the plasma from the obese group which had insulin activity. There was no insulin activity in the plasma of two insulin-resistant diabetics 
TABle II

Insulin Activity of Plasma from Diabetic Patients

\begin{tabular}{|c|c|c|c|c|}
\hline Type of Diabetic & Method of Assay & $\begin{array}{l}\text { Plasma Insulin } \\
\text { Activity } \\
\text { micro-units/ml. }\end{array}$ & Condition & Investigator \\
\hline Mild Obese & ADHA rat & 230 & 2 hours after glucose & Bornstein and Lawrence \\
\hline Mild Obese & $\begin{array}{l}\text { Rat diaphragm with } \\
\text { undiluted plasma }\end{array}$ & $\begin{array}{r}50-300 \\
250-600\end{array}$ & $\begin{array}{l}\text { Fasting } \\
\text { I hour after glucose }\end{array}$ & Vallance-Owen et al. \\
\hline Mild Obese & $\begin{array}{l}\text { Rat diaphragm with } \\
\text { undiluted plasma }\end{array}$ & Normal levels & $\begin{array}{l}\text { Fasting and after } \\
\text { glucose }\end{array}$ & Wright (1957) \\
\hline Mild Obese & $\begin{array}{l}\text { Rat diaphragm with di- } \\
\text { luted plasma }\end{array}$ & Normal levels & Not stated & $\begin{array}{l}\text { Willebrands and Groen } \\
(1956)\end{array}$ \\
\hline Mild Obese & $\begin{array}{l}\text { Rat diaphragm with di- } \\
\text { luted plasma }\end{array}$ & Normal levels & Not stated & Randle (1957) \\
\hline $\begin{array}{l}\text { Insulin-Requiring } \\
\text { Untreated }\end{array}$ & ADHA rat & None detected & 2 hours after glucose & Bornstein and Lawrence \\
\hline Treated & ADHA rat & & 2 hours after glucose & Bornstein and Lawrence \\
\hline $\begin{array}{l}\text { Untreated or un- } \\
\text { controlled }\end{array}$ & $\begin{array}{l}\text { Rat diaphragm with } \\
\text { undiluted plasma }\end{array}$ & & $\begin{array}{l}\text { Fasting or I hour after } \\
\text { insulin injection }\end{array}$ & $\begin{array}{l}\text { Vallance-Owen et al. } \\
\text { (1955) }\end{array}$ \\
\hline Well controlled & $\begin{array}{l}\text { Rat diaphragm with } \\
\text { undiluted plasma }\end{array}$ & Normal levels & $\begin{array}{l}\text { Fasting or I hour after } \\
\text { insulin injection }\end{array}$ & $\underset{(1955)}{\text { Vallance-Owen et al. }}$ \\
\hline $\begin{array}{l}\text { Untreated or } \\
\text { treated }\end{array}$ & $\begin{array}{l}\text { Rat diaphragm with di- } \\
\text { luted plasma }\end{array}$ & Normal levels & Not stated & $\begin{array}{l}\text { Groen et al. }(1952 \\
\text { Willebrands and Groen }\end{array}$ \\
\hline $\begin{array}{l}\text { Untreated or } \\
\text { treated }\end{array}$ & $\begin{array}{l}\text { Rat diaphragm with di- } \\
\text { luted plasma }\end{array}$ & Normal levels & Not stated & Randle (r957) \\
\hline
\end{tabular}

whose blood sugar was elevated even one hour after an injection of 300 units insulin.

Investigators using whole undiluted plasma with the rat diaphragm technique have recorded somewhat similar results (Vallance-Owen et al., 1955).

Insulin activity was found in the plasma of all patients in the obese diabetic group. The range, in the fasting state, was from 50 to 300 microunits $/ \mathrm{ml}$. with an overall mean of 125 microunits/ml., which is above that found in normal fasting subjects. Increased insulin activity was usually found after glucose. The range now was from 250 to 600 micro-units $/ \mathrm{ml}$. with a mean of 430 micro-units $/ \mathrm{ml}$., which was not dissimilar to that found in normal subjects under the same conditions.

When insulin was added in vitro to the plasma from these diabetics the activity of the added insulin was not diminished, i.e. there was no demonstrable antagonism, which is similar to the findings in normal subjects.

Turning now to the group of diabetics who require insulin treatment to prevent ketosis: if these patients were untreated or uncontrolled at the time of the test no plasma insulin activity was found, even though they might have received a substantial injection of insulin one hour before the blood was withdrawn for testing. Moreover, when insulin was added in vitro to the plasma from these patients the activity of the added insulin was inhibited and markedly diminished.
If, however, these patients were controlled witlo ํํㅇ insulin, so that their blood sugar level was physio logical at the time of the test, plasma insuling activity was again found, essentially in the normal range, and insulin added in vitro was no longer inhibited. It must be stressed again that all the above observations were carried out using undiluted plasma for the assay. If inhibiting plasma with no insulin activity from uncontrolled insulinrequiring diabetics was diluted $I: 4$ prior to the assay, then insulin activity was found in this plasma, and now there was no inhibition of any additional insulin. It is important to remember that these patients were not separated from insulin therapy for longer than, at the most, 24 hours. Therefore, this finding on dilution does not indicate that there is necessarily any endogenous insulin in their plasma, although this may be so. It only reveals the activity of the exogenous insulin which was administered to them, either one hour before the test was performed or the previous day, and is masked by the inhibitor in undiluted plasma. Nevertheless, this observation could explain the findings of investigators who have studied diabetic patients using diluted plasma in the assay procedure. Such investigators (Groen, 1952; Randle, 1957) have found no difference between the two diabetic groups or between them and normal subjects with respect to plasma insulin activity, except in diabetic coma, when no insulin activity was found. 
The results obtained in diabetic patients by the in vivo and in vitro techniques are summarized in Table 2.

\section{Discussion \\ Mild Obese Diabetics}

Although near normal values for plasma insulin activity have been found in the mild obese group of diabetics, it would be incorrect to believe that the pancreas is therefore acting normally here.

The amount of insulin produced by the pancreas of a normal subject against the blood sugar-level ordinarily maintained by these diabetics would probably be very much greater than is actually found in these patients. This point has not yet been investigated by direct measurement of insulin activity. However, there is good indirect evidence that more insulin is produced under such circumstances by normal subjects derived from glucose assimilation studies following intravenous infusions of glucose. In other words, sufficient insulin can be produced by the pancreas of these mild diabetics for ordinary requirements, but there is less than the normal functional reserve, which, in turn, is probably genetically determined. This reserve is inadequate with obesity, when more insulin is required for normal metabolism. Hence the amelioration of the diabetic state with weight reduction in many of these patients.

When insulin is added in vitro to the plasma from these patients there is no demonstrable antagonism. Thus the well-known resistance to insulin which these obese diabetics exhibit presumably resides in the tissues.

\section{Insulin-requiring Diabetics}

When such patients are uncontrolled there is no measurable plasma insulin activity and any insulin added to their plasma in vitro is inhibited.

This observation suggests that these diabetics require insulin to overcome some antagonist circulating in their plasma. In order to achieve control sufficient insulin must be given to counteract this antagonism and yet leave sufficient active or free insulin to carry out its normal functions. It is entirely possible, at least initially, that there is some endogenous insulin production in these patients which is completely obscured by the antagonistic activity. The insulin antagonism found in these uncontrolled insulin-requiring diabetics may be an exaggeration of the situation in normal subjects where the antagonism is completely masked by adequate insulin production by the pancreas. In animals this antagonism can be revealed by pancreatectomy (Vallance-Owen and Lukens, 1957).

It has recently been shown that the antagonism to insulin found in the plasma of these patients resides in the albumin fraction of the plasma proteins (Vallance-Owen et al., 1958a). Similar antagonism has also been found in the plasma albumin fraction from., normal subjects, but the fraction from normal subjects is less active in this respect. A possible explanation for the difference would be that the antagonism is not due to albumin per se, but to some substance bound to it, in larger amounts on diabetic albumin than on normal albumin.

It has now been found that albumin prepared from the plasma of insulin-requiring diabetics and normal subjects, when passed through a column of partially acetylated cellulose (Campbell and Stone, 195I), loses its antagonistic activity to insulin, although still electrophoretrically identical with albumin (Vallance-Owen et al., 1958b). Also it was observed that the plasma albumin fraction from hypophysectomized patients was devoid of insulin antagonism.

Taken together, both these lines of evidence strongly suggest that the activity of the albumin fraction from normal subjects and diabetic patients against insulin is not due to albumin per se, but to a substance associated with it.

The results of hypophysectomy indicate that the antagonistic activity is related, possibly indirectly, to the pituitary gland. This organ may not be solely responsible, however, as can be seen from studies made on experimental diabetes in animals (Vallance-Owen and Lukens, 1957).

\section{Experimental Diabetes in Animals}

As with normal subjects, the plasma from normal fasting cats had insulin activity, but no measurable antagonism to added insulin.

There was no insulin activity in the plasma from depancreatized cats, as might be expected, and such plasma also inhibited the activity of any insulin added in vitro, i.e. an experimental situation was obtained which was not dissimilar to that found with uncontrolled insulin - requiring diabetic patients.

This inhibition of insulin in the plasma from depancreatized cats could be abolished either by hypophysectomy or bilateral adrenalectomy.

In either depancreatized-hypophysectomized (Houssay) or depancreatized-adrenalectomized (Long-Lukens) cats there was again no plasma insulin activity, but now the activity of insulin added to the plasma was fully recovered.

Cortisone or hydrocortisone, Io mg. per day, injected subcutaneously for four days into the Long-Lukens type of animal, restored the inhibitory properties of the plasma. The same dose of hydrocortisone injected into Houssay cats for four days and even longer, until severe ketosis was 


\section{TABLE III}

Insulin ANtagonism of Plasma from variously TREATED CATS

(Method of Assay-Rat Diaphragm with undiluted plasma)

Vallance-Owen and Lukens, 1957

\begin{tabular}{|c|c|c|c|}
\hline Type of Animal & & & $\begin{array}{l}\text { Antagonism of } \\
\text { Insulin added } \\
\text { in vitro }\end{array}$ \\
\hline $\begin{array}{l}\text { Normal } \quad . . \\
\text { Depancreatized } \quad . \\
\text { Depan.-Hypox. } \quad . \cdot \\
\text { Depan.-Hypox. + F. } \\
\text { Depan.-Hypox. + G.H. } \\
\text { Depan.-Adrex. } \\
\text { Depan.-Adrex. + E. or F. } \\
\text { Depan.-Adrex. + G.H. }\end{array}$ & $\begin{array}{l}\ldots \\
\ldots \\
\cdots \\
\ldots \\
\ldots \\
\ldots\end{array}$ & $\begin{array}{l}. \\
\because \\
\because \\
\because \\
\because \\
\cdots\end{array}$ & $\begin{array}{l}\text { No } \\
\text { Yes } \\
\text { No } \\
\text { No } \\
\text { No } \\
\text { No } \\
\text { Yes } \\
\text { No }\end{array}$ \\
\hline
\end{tabular}

$\mathrm{F}=$ Hydrocortisone acetate; $\mathrm{E}=$ Cortisone acetate; G.H.=Growth Hormone; Hypox.=Hypophysectomized; Adrex.=Adrenalectomized.

produced, did not restore the inhibitory activity of the plasma from these animals.

Growth hormone (3 mg./day for four days) injected subcutaneously into either Long-Lukens or Houssay cats failed to restore the inhibiting properties of the plasma. Table 3 summarises the results, which indicate that both the pituitary gland and the adrenal corticalsteroids must be present for insulin antagonism to be found in the plasma of depancreatized cats. It is not known, as yet, whether the antagonism in these animals is carried in the same plasma protein fraction as that found in normal subjects and insulin-requiring diabetics.

In view of the apparent arrest of diabetic complications by hypohysectomy or adrenalectomy, the above observations have more than theoretical interest. For, through further study of insulin antagonism, we may learn something more, not only about the fundamental nature of diabetes but also about the cause and subsequent prevention of the serious complications which are so often associated with this disease.

\section{Summary}

Several highly sensitive methods for measuring insulin activity in plasma are now available. Although none of them are entirely satisfactory, they have yielded interesting results in relation to plasma insulin activity in diabetes mellitus.

The mild obese group of diabetics, who do not require insulin treatment, have near normal levels of plasma insulin activity in the fasting state. There is usually a rise in activity after glucose by mouth as in normal subjects and also added insulin is satisfactorily recovered. Thus the wellknown resistance to insulin which these patients exhibit does not reside in the plasma and presumably is present in the tissues.

Untreated or uncontrolled insulin-requiring diabetics have no measurable plasma insulin activity. Moreover, when insulin is added to the plasma from these patients, its activity is apparently inhibited. If the patients in this group are controlled, however, plasma insulin activity is again found, essentially in the normal range and added insulin can now be recovered. In view of this antagonism, the amount of endogenous insulin produced by these patients is not known.

The antagonism to insulin noted in these insulinrequiring diabetics is probably an exaggeration of the situation in normal subjects where the antagonism is masked by adequate insulin production by the pancreas. In both situations the antagonism resides in the albumin fraction of the plasma.

It is apparently not due to albumin per se but to some substance associated with it related, - possibly indirectly, to the pituitary gland. This organ may not be solely responsible, however, as is suggested from studies on experimental diabetes in animals. Thus insulin antagonism in the plasma of depancreatized cats is dependent upon the presence of both the pituitary gland and the adrenal cortical steroids.

Certain sections of this article will appear in a book entitled Diabetes to be edited by Dr. Robert H. Williams, and published by Paul B. Hoeber, Inc., Medical Book Department of Harper Brothers, New York.

\section{BIBLIOGRAPHY}

ANDERSON, E., LINDER, E., and SUTTON, V., Amer. $\mathcal{F}$. Physiol., 149, 350.

BORNSTEIN, J. (1950), Aust. F. Exp. Biol. med. Sci., 28, 87.

BORNSTEIN, J., and LAWRENCE, R. D. (1951), Brit. med. F., ii, $\mathrm{r}, 54 \mathrm{r}$.

CAMPBELL, P. N., and STONE, N. E. (195I), Biochem. F., 66, 19. GELLHORN, E., FELDMAN, J., and ALLEN, A. (1941), Endocrinology, 29, 137.

GEMMILL, C. L. (194I), Bull. Fohns Hopk. Hosp., 68, 329.

GROEN, J., KAMMINGA, C. E., WILLEBRANDS, A. F., and BLICKMAN, J. R. (1952), f. clin. Invest., 31, 97.

HIMSWORTH, H. P. (1949), Lancet, i, 465.

LAWRENCE, R. D. (1951), Brit. med. F., i, 373.

MARTIN, D. B., RENOLD, A. E., and DAGENAIS; Y. M. (1958), Lancet, ii, 76.

RANDLE, P. J. (1954), Brit. med. F., 1, 1,237.

RANDLE, P. J. (1957), 'Ciba Foundation Colloquia on Endocrinology,' Vol. III, ' Hormones in Blood,' p. I15, London, Churchill.

RANDLE, P. J., and TAYLOR, K. W. (1958), Y. Endocr., 17, 387. VALLANCF-OWEN, J., and HURLOCK, B. (1954), Lancet, i, 68. VALLANCF-OWEN, J., HURLOCK, B., and PLEASE, N. W. (I955), Jbid., ii, 583.

VALLANCF-OWEN, J., and LUKENS, F. D. W. (1957), Endocrinology. 60, 625.

VALLANCF-OWEN, J., DENNES, E., and CAMPBELL, P. N. (1958a), Lancet, 1i, 336.

VALLANCF-OWEN, J., DENNES, E., and CAMPBELL, P. N. (1958b), Ibid., ii, 696 .

WILLEBRANDS, A. F., and GROEN, J. (1956), Diabetes, 5, 378. WRIGHT, F. H. (1957), Lancet, ii, 621. 